\title{
Germination of spineless Bromelia laciniosa Mart. ex Schult (Bromeliaceae) seeds subjected to chemical scarification
}

\author{
Germinación de semillas de Bromelia laciniosa Mart. ex Schult (Bromeliaceae) sin \\ espinas sometidas a la escarificación química
}

\author{
Moadir de Sousa Leite ${ }^{1}$, Luiz Aurélio Freitas Pereira', Francisco de Queiroz Porto Filho', Tiago de \\ Sousa Leite ${ }^{2}$ and Salvador Barros Torres ${ }^{1 *}$
}

\begin{abstract}
Bromelia laciniosa, popularly known as 'macambira', is a plant found mainly in dry areas of northeast Brazil. This species belongs to the Family Bromeliaceae, whose propagation has been hindered by seed dormancy. This study aimed to evaluate the effectiveness of chemical scarification in the germination of $B$. laciniosa seeds at two maturation stages, by immersing them in acetone or alcohol for 30, 60 or 90 minutes. Immersing B. laciniosa seeds in acetone (58\%) for 90 minutes proved to be an effective method to overcome dormancy. Seeds from mature fruits showed higher germination values.
\end{abstract}

Keywords: Bromeliaceae, dormancy, macambira.

\section{RESUMEN}

Bromelia laciniosa, conocida popularmente como "macambira", es una planta encontrada principalmente en áreas secas del Nordeste brasileño. Esta especie pertenece a la familia Bromeliaceae, cuyo fenómeno del adormecimiento en semillas ha dificultado su propagación. En el presente estudio se evaluó la eficiencia de la escarificación química en la germinación de semillas de B. laciniosa, en dos estados de maduración, utilizando acetona y alcohol por 30, 60 y 90 minutos de inmersión de las semillas. La inmersión de las semillas de B. laciniosa en acetona (58\%) por 90 minutos se constituye en un eficiente método para la superación del adormecimiento. Las semillas oriundas de frutos maduros proporcionan mayores valores de germinación.

Palabras clave: Bromeliaceae, dormancia, macambira.

\section{Introduction}

Bromelialaciniosa Mart.ex. Schult(Bromeliaceae) is a species endemic to the Caatinga biome, where it is widely distributed and popularly known as 'macambira' (Santo et al., 2012). This plant is used for medicinal purposes, landscaping and as a complement in animal and human food, especially during the long periods of drought in the northeastern semi-arid region of Brazil (Angelim et al., 2007; Dutra et al., 2010; Oliveira Júnior et al., 2017).
Seed dormancy has often been reported for the Bromeliaceae (Dutra et al., 2010; Coelho et al., 2011). Pre-germination treatments with immersion in acetone for 60 minutes promoted significant increases in the germination of B. laciniosa seeds (Dutra et al., 2010), while for B. balansae, Coelho et al. (2011) observed that dormancy was overcome by immersing the seeds in sulfuric acid (98\%) for one minute.

Despite the growing demand for bromeliads in Brazilian landscaping, they are still poorly studied, especially with regard to seed germination (Pereira

\footnotetext{
Center of Agrarian Science, Federal Rural University of the Semi-Arid, Mossoró, Rio Grande do Norte, Brazil.

2 Department of Soil Science, University of São Paulo. Piracicaba. São Paulo, Brazil.

Corresponding author: sbtorres@ufersa.edu.br.
} 
et al., 2010). Other problems pointed out for these plants are the long flowering period and the lack of uniformity in the fruit maturation process (Molizane et al., 2013), increasing the need for research on the ideal harvesting point, which for many species is based on fruit color.

Therefore, this study aimed to evaluate the effectiveness of different pre-germination treatments in the germination of B. laciniosa seeds at two maturation stages.

\section{Material and Methods}

Green (immature seeds) and yellow (mature seeds) B. laciniosa fruits were collected from plants grown in Upanema (053' $\mathrm{S}, 37^{\circ} 15^{\prime} \mathrm{W}$; $47 \mathrm{~m}$ above sea level), Rio Grande do Norte, Brazil. The seeds were extracted, washed and allowed to dry in the shade under ambient temperature $\left(25-30^{\circ} \mathrm{C}\right)$. Then they were packed in paper bags and stored in a cold room $\left(10{ }^{\circ} \mathrm{C}\right.$ and $50 \%$ relative humidity) until the beginning of the experiment.

Treatments consisted of immersing the seeds in acetone (58\%) or alcohol (70\%) for 30,60 or 90 minutes, and then washing them in running water for two minutes.
Non-scarified (control) seeds were also washed under the same conditions, aiming to eliminate differences in imbibition. For each treatment, four replicates of 25 seeds were placed in Petri dishes containing three sheets of filter paper which had been previously moistened with an amount of water equivalent to 2.5 times their dry weight. The dishes were maintained at $30^{\circ} \mathrm{C}$ and subjected daily to 8 hours light and 16 hours darkness, as recommended by Dutra et al. (2010). The germination test was carried out for 12 days, and seeds were considered germinated when the radicle was at least $0.3 \mathrm{~cm}$ long. The mean germination time was calculated based on the method proposed by Maguire (1962), taking into account the number of days to each count (performed daily after the beginning of germination).

\section{Results and Discussion}

There were significant differencesin germination percentage among the treatments (Tukey, $P<0.05$ ); seeds treated with acetone and alcohol showed values higher than those observed for the control (Figure 1A). Immersion in acetone for 90 minutes increased the germination of mature seeds from $43 \%$ (control)
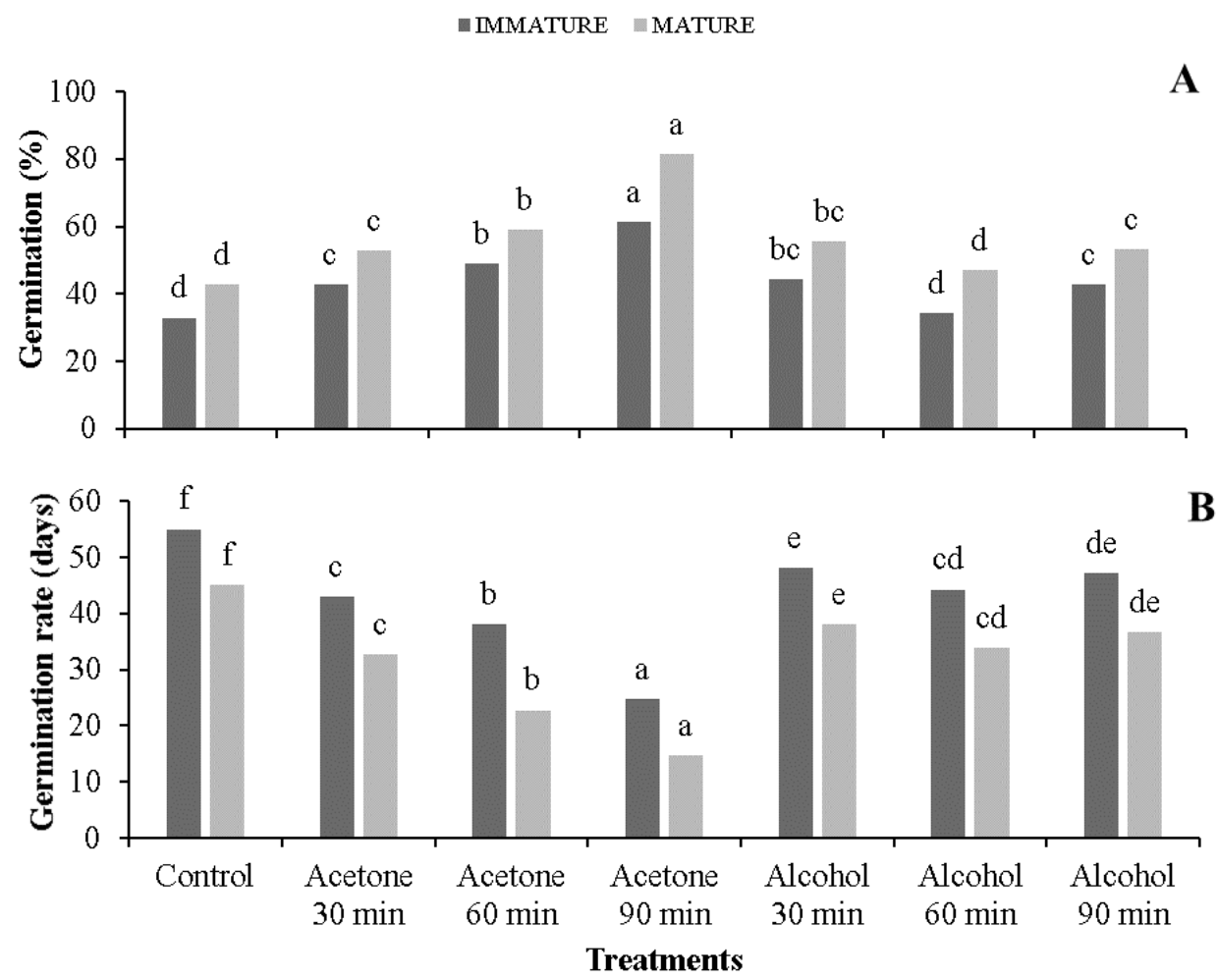

Figure 1. Mean germination (A) and germination time (B) of immature (dark grey) and mature (light grey) Bromelia laciniosa Mart. ex Schult seeds immersed in acetone (58\%) and alcohol (70\%) for different periods, compared to an untreated control. Different letters above the columns indicate significant differences (Tukey, $\mathrm{P}<0.05$ ). 
to $82 \%$. Immersion in alcohol for 30 minutes resulted in a $13 \%$ increase in the germination of mature seeds in relation to the control treatment. As observed for the germination percentage, treatment with acetone for 90 minutes provided the best results for the germination time of mature seeds (Figure 1B), which was considerably reduced in relation to all other treatments. The ideal immersion time using alcohol was 60 minutes, although it was not as effective as the aforementioned treatment.

Mature seeds (yellow fruits) showed higher germination percentage and lower germination time compared to immature seeds (green fruits) for all the treatments. At physiological maturity seeds reach their maximum physiological quality, vigor, germination, size and dry weight (Carvalho e Nakagawa, 2012). Therefore, green seeds (physiologically immature) show lower potential to germinate than mature seeds.

There are seeds that due to physical and chemical characteristics of their coat present mechanical and/ or chemical inhibition of germination (Bewley et al., 2013), a phenomenon observed for many bromeliads.
Several methods may be employed to overcome seed dormancy before sowing in order to enhance the rate and uniformity of germination (Turner et al., 2013). According to Baskin \& Baskin (2001), for seeds with physical dormancy (coat impermeable to water), treatments may include immersion in hot water and mechanical or chemical scarification.

Our results are consistent with those of Dutra et al. (2010), who reported increased and accelerated germination of $B$. laciniosa seeds after immersion in acetone for 30 and 60 minutes. The best results for the variables analyzed here were obtained after immersing the seeds in acetone for a period longer than that proposed by Dutra et al. (2010), with 90 minutes being the most appropriate time for this species.

\section{Conclusions}

Immersing B. laciniosa seeds in acetone (58\%) for 90 minutes proved to be an effective method to overcome dormancy. Seeds from mature fruits showed higher germination values.

\section{Literature Cited}

Angelim, A.E.S.;Moraes, J.P.S.; Silva, J.A.B. \& Gervásio, R.C.R.G. 2007. Germinação e aspectos morfológicos de plantas de macambira (Bromelia lacioniosa), encontradas na região do Vale do São Francisco. Revista Brasileira de Biociências, 5 (2): 1065-1067.

Baskin, C.C.; Baskin, J.M.

2001. Seeds: ecology biogeography and evolution of dormancy and germination. Academic Press, San Diego, CA, US. 666p.

Bewley, J.D.; Bradford, K.; Hilhorst, H.; nonogaki, H.

2013. Seeds: physiology of development, germination and dormancy. 3.ed. Springer. NY.US. 392p.

Carvalho, N.M.; Nakagawa, J.

2012. Sementes: ciência, tecnologia e produção. 5 ed. FUNEP. Jaboticabal, Brazil. 588p.

Coelho, M.F.B.; Vieira, S.N.; Chig, L.A., Santos, L.W.; Albuquerque; M.C.F.

2011. Superação da dormência em sementes de Bromelia balansae (Bromeliaceae). Horticultura Brasileira, 29 (4): 472-476.

Dutra, A., Teófilo, E.M.; Medeiros Filho, S.

2010. Germinação de sementes de macambira (Bromelia laciniosa Mart. ex Schult). Revista Caatinga, 23 (2): 12-17.

Maguire, J.D.

1962. Speed of germination: aid in selection and evaluation for seedling emergence and vigor. Crop Science, 2 (2): 176-177.
Molizane, D.M.; Kanashiro, S.; Tavares, A.; Barbedo, C.J. 2013. Maturação de sementes de Aechmea bromeliifolia (Rudge) Baker e Vriesea paraibica Wawra (Bromeliaceae). Hoehnea, 40 (4): 619-625.

Oliveira-Júnior, R.G.; Alves Ferraz, C.A.; Rocha Souza, G.; Leite Guimarães, A., Oliveira, A.P.; Gomes de Lima-Saraiva, S.R.; Araújo Rolim, L.; Rolim-Neto, P.J.; Guedes da Silva Almeida, J.R.

2017. Phytochemical analysis and evaluation of antioxidant and photoprotective activities of extracts from flowers of Bromelia laciniosa (Bromeliaceae). Biotechnology \& Biotechnological Equipment, 31 (3): 600-605.

Pereira, C.; Cuquel, F.L.; Panobianco, M.

2010. Germinação e armazenamento de sementes de Nidularium innocentii (Lem.). Revista Brasileira de Sementes 32 (2): 36-41.

Santo, F.S.E. et al.

2012. Impacto da herbivoria por caprinos sobre as populações naturais de Bromelia laciniosa Mart. ex. Schult. f. (Bromeliaceae), Revista Árvore, 36 (1): 143-149.

Santo, F. da S. do E.; Maciel, J.R.; Siqueira Filho, J.A. de. 2013. Seed treatment optimizes benefits of seed bank storage for restoration-ready seeds: The feasibility of prestorage dormancy alleviation for mine-site revegetation, Restoration Ecology, 21 (2): 186-192. 